UDC 81'23

Research article

LBC 100.3

DOI 10.30982/2077-5911-2021-49-3-74-85

\title{
GENDER, GRAMMAR AND DISCOURSE: THE CASE OF GERMAN ${ }^{1}$
}

\author{
Ursula Doleschal \\ Alpen-Adria-Universität Klagenfurt, Institut für Slawistik, Klagenfurt, Austria
}

\begin{abstract}
In this article, we try to show how the discourse about grammatical and natural gender has changed over time starting with grammars from the $16^{\text {th }}$ and $17^{\text {th }}$ century, where we find a neutral and symmetric presentation of the genders, through the $18^{\text {th }}$ and $19^{\text {th }}$ centuries, when this discourse radically changes, up to the end of the $20^{\text {th }}$ century, where we again reach a neutral presentation which is less symmetrical, though.
\end{abstract}

Keywords: gender, German, grammar

\section{ГЕНДЕР, ГРАММАТИКА И ДИСКУРС: НА ПРИМЕРЕ НЕМЕЦКОГО ЯЗЫКА}

\author{
Урсула Долешаль \\ Alpen-Adria-Universität Klagenfurt, Институт славистики, \\ Клагенфурт, Австрия
}

\section{Аннотация}

В статье автор стремится показать, как лингвистические взгляды о связи грамматического рода с биологическим полом человека менялись с течением времени, начиная с грамматик XVI-XVII в.в., где мы находим нейтральное и симметричное представление мужского и женского рода, далее в XVIII-XIX в.в., когда эти рассуждения радикально меняются, и, наконец, в XX в., где мы снова имеем нейтральное соотношение мужского и женского рода, которое, однако, менее симметрично, чем в XVI-XVII вв.

Ключевые слова: гендер, немецкий язык, грамматика

\section{Introduction}

In this article, we will speak about language ideologies. Language ideologies can be folk ideologies, but they can also arise within or be corroborated by theoretical linguistic literature. Linguistic theories, as all science, are not independent from their historical

\footnotetext{
${ }^{1}$ First published as: "Rod, gramatika i diskurs: slučaj nemačkog jezika”. In: V. Vasić (Hrsg.): Diskurs i diskursi: zbornik u čast Svenki Savić. Novi Sad: Faculty of Philosophy at the University of Novi Sad, 2010, pp. $107-119$ (in Serbian).
} 
context. And so, any theoretical description of language reflects - to a greater or lesser extent - the way of thinking of a historical epoch.

In this article, I will try to show how the discourse about grammatical gender as a linguistic category is intertwined with the discourse about natural gender, i.e., about women and men, and how this discourse is historically situated. My material consists of grammars and manuals of style of German from the $16^{\text {th }}$ century until the end of the $20^{\text {th }}$ century $(\mathrm{cp}$. "Sources" below, and [Jellinek 1913-1914, Naumann 1986, Roessler 1997, Žepić 1998]).² The periodization will largely follow [Laqueur 1990].

The present analysis aims at answering the following questions:

1. How is grammatical gender defined in the grammars, i.e., is grammatical gender related to natural gender? If so, how is this relationship conceived of?

2. How is the derivation of nouns denoting men and nouns denoting women described?

3. What other aspects of the gender difference are negotiated in the grammars and manuals?

To this end, I have investigated all chapters in a grammar or manual of style where either the category of grammatical gender or natural gender is treated.

As Laqueur [1990] writes, natural gender (or sex), as a category that fundamentally distinguishes women from men, has a rather complex history in European thinking, as evidenced by the history of medicine. For many centuries the female sex (in the sense of sexual organs) was conceived of as a complementary category of the male sex. Both sexes were understood as different but of equal nature. This traditional view changed radically with the period of Enlightenment, i.e., in the 18th century. Laqueur shows this by the analysis of written and pictorial documents. In the present article, we will show the same thing by analysing the discourse of grammars.

\section{The investigation}

The discourse about grammatical gender and its relation to natural gender has changed over time. In the first period under investigation, Renaissance and Baroque, grammatical gender is seen as a feature of both the noun and the adjective. The authors ${ }^{3}$ classify nouns according to their agreement behaviour on the one hand; on the other hand - according to their semantic potential to designate beings of male or female sex. So, Clajus, e.g., arrives at seven genders. Five are defined on the basis of agreement by the article in that there are masculine nouns with the article $\operatorname{der}$ (der Man - 'the.m man'), feminine nouns with the article die (die Frawe - 'the.f woman') and neutral nouns with the article das (das Haus - 'the.n house'), common nouns agreeing both with the article der and die ('der or die Gevatter' - 'the.m or the.f godfather') and the gender called "general" which is ascribed to adjectives, as they take all three articles (der - 'the.m', die - 'the.f', das - 'the.n'). The

\footnotetext{
${ }^{2}$ The selection of grammars, although aiming at representativity, is unfortunately far from complete and should be improved in the future.

${ }^{3}$ We refer to [Albertus 1573, Oelinger 1574, Clajus 1578, Ritter 1616, Gueintz 1641, Schottel 1663, Stieler 1691, Bödiker 1698].
} 
sixth gender is the so called "epicaenum" (epicene) and comprises those nouns which have only one article but can refer to both sexes, as do designations of animals (der Sperling 'the.m sparrow'). And lastly, there is the "genus dubium", the dubious gender, comprising those nouns which show variation as to their article (der teil \& das teil - 'the.m part \& the.n part').

As we can see from the cited passage, grammatical gender and natural gender are not strictly separated in this period of grammaticography, but, at the same time, the exact nature of their relationship is not explained, and neither is a dependency relation between the two discerned. Grammatical gender is somehow related to natural gender, in that the "general rules" of recognizing the gender of a noun comprise formulations as: "Virorum, officiorum virilium, mensium, ventorum, \& quadrantum anni nomina sunt generis Masculini. (...)

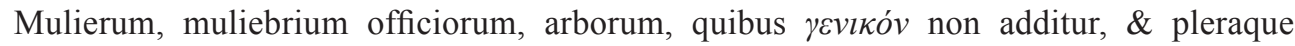
fructum ac fluviorum nomina sunt generis Foeminini." ('The nouns/names of men, male offices, months, winds and points of the compass are of masculine gender (...) the nouns/ names of women, female offices, trees without their generic noun, and most nouns/names of fruits and rivers are of feminine gender'). ${ }^{4}$ This formulation is repeated in a more or less identical manner in the grammars of German until the $18^{\text {th }}$ century.

If we look at the derivation of female nouns from male ones by the suffix -inn, we also find a quite laconic description stating that: "Auf -inn ausgehende sind alle Weibliches Geschlechts bedeutend den Nahmen, die Person oder Ankunft des Weibes, werden meisten Theils von der Haubtendung -er welche den Nahmen, die Ankunft oder Person des Mannes andeutet formiret." ("[Those] ending in -inn are all of feminine gender denoting the name, the person or origin of the woman, are mostly formed from the main ending -er which indicates the name, the origin or person of the man'). Such a formulation implies parallelity of male and female. This parallelity can also be seen in other parts of the grammars, e.g., in the lexemes used for exemplifying the different forms of the adjective: "der gelerte man, die gelerte fraw, das gelerte mensch" ('the.m learned man, the.f learned woman, the.n learned human' [Oelinger 1574: 26]); “der Mann ist stark, die Frau ist stark, das Tihr ist stark" ("the man is strong, the woman is strong, the animal is strong' [Schottel 1663: 262]), "Liebender, -de, -des; Geliebter, -te, -tes." ('loving -m, -f, -n'; 'beloved -m, -f, -n' [Gueintz 1641: 84] and [Stieler 1691: 62]): the same attributes are ascribed to men, women, and animals as well. We do not find any cases of stereotypisation. Moreover, the attributes are all a virtuous nature.

In the following period of Enlightenment, we notice a change in the discursive practice of grammaticography, which is certainly not accidentally paralleled by a change of view in medicine of that time [Laqueur 1990, ch. 5]. Let us first look at the influential work "Deutsche Sprachkunst" by Johann Christoph Gottsched [1749, 1762]. It is here that for the first time a philosophical passage of about one page is introduced trying to give reasons for the existence of the (now, since [Schottel 1663]) three grammatical genders of German. Gottsched ([1762], cited according to [Mitchell 1978: 197-198]) states that German has three genders because of the fact that human beings and animals distinguish two sexes but

\footnotetext{
${ }^{4}$ [Clajus 1578], cited according to [Weidling 1894: 26-27].

${ }^{5}$ [Schottel 1663: 355-356], as examplary for the discourse of the 16th and 17th centuries.
} 
there are many other things which are neither man nor woman and therefore he calls the third gender the "dubious" ("ungewiss") one: "\$9 Da Menschen und Thiere von zweyerley Geschlechtern; außer diesen aber, viele andere Dinge, weder Mann noch Weib sind, sondern ein unbestimmtes Geschlecht ausmachen: so hat man auch in den Wörtern der Sprachen dreyerley Geschlechter, nämlich das männliche, weibliche und ungewisse eingeführet."

He argues that this is the term that should be preferred against "thingly" ("dinglich"), because when using words like das Kind ('the.n child'), das Thier ('the.n animal') it remains unclear if we are speaking of a male or a female being. According to Gottsched, it is to be blamed on the inconsistency of the plebs who in the first place made the language that there is no unique relationship between the semantics and the grammatical gender of nouns in German, especially the fact that there are nouns denoting male or female beings (diminutives) which are of neuter, i.e., “dubious”, gender, as Knäblein ('little boy'), Töchterlein ('little daughter'), but also nouns for denoting unsexed things which have masculine or feminine gender.

It is interesting to note that although the argumentation starts from a natural classification of beings in sexed - male and female - and unsexed ones and relates this threefold classification to the grammatical classes found in language, it is nevertheless not argued that this relationship existed from the beginning and changed with the course of history. On the contrary, Gottsched seems to assume that an inconsistency between natural and grammatical gender has existed right from the beginning of the "making of language", because, as he writes, it was the plebs who made language. Such a view is interesting from the point of view of a language ideology, because the categories of language are not seen as something created and imposed by god or any other higher instance.

Nevertheless, Gottsched believes that the relationship between natural and grammatical gender is "grounded in the essence of things." This conclusion is based on the regularity of the relationship between the masculine gender and the male sex, which, as he states, is "without exception" ("Diese Regel hat gar keine Ausnahme; weil sie sich auf das Wesen der Dinge gründet (...)" [Gottsched 1749: 171-172, 1762, cited according to Mitchell 1978: 248]), although he immediately has to admit the inconsistent neuters as Knäblein ('little boy'), Söhnlein ('little son'). However, he plays this inconsistency in the masculine gender down, arguing that it is a consequence of certain syllables, whereas for the feminine he emphasizes the same inconsistency between female sex and grammatical gender, as evidenced by neuters as Weib ('woman'). It is of course true from the point of view of contemporary linguistics that gender assignment by suffixes as -lein takes place on another level of linguistic structure than the neuter gender of a monomorphemic word as Weib ('woman') which was at the same time the basic word for designating a woman. Nevertheless, Gottsched's highlighting of this one contrast in consistency between masculine/male and feminine/female shows that the two genders are not treated equally. This can also be deduced from the formulation of the rules for discerning gender themselves: these rules are formulated in a similar but not identical way as compared to earlier grammars. For the masculine gender the first rule is: "Wörter, die männliche Namen, Ämter, Würden oder Verrichtungen bedeuten, sind auch männliches Geschlechtes.” (Gottsched, op.cit., boldface in the original; "words that denote male names, offices, ranks or occupations are also of masculine gender'). For the feminine gender the rule sounds: "Alle Namen und Benennungen, Ämter, Titel, Würden und Verrichtungen des Frauenvolkes 
sind weibliches Geschlechtes" (Gottsched, op.cit., boldface in the original; "all names and designations, offices, titles, ranks and occupations of womenfolk are of feminine gender'). Firstly, men and women are not introduced parallely: men are designated only by the adjective "männlich" ('male'), whereas women are named by a collecitve noun "Frauenvolk" ('womenfolk'), which sounds somewhat condescending. Secondly, the examples that illustrate the two rules are given as a whole block for the masculine gender: “Z.E. der Kaiser, der König, der Herzog, der Fürst, der Graf, der Herr, der Mann" (e.g., 'the emperor, the king, the duke, the prince, the earl, the lord, the man'). For the feminine gender, on the other hand, the examples are itemized according to the classes named (names and designations, offices, titles, ranks and occupations). Therefore, according to Gottsched, kinship terms as Base 'cousin', Schwester 'sister' etc. are designations, certain ranks, on the other hand, are "titles", as Äbtissinn 'abbess' or Gräfinn 'countess', whereas nouns as Dichterinn, Poetinn 'poetess' as well as again Gräfinn 'countess', Prophetinn 'prophet' and others are "ranks". In the last place he has occupations, such as Bäuerinn 'peasant', Köchinn 'cook' etc.

We can note another inconsistency here, which is this time due to the author, not to the language system: although he introduces the class "offices", he, nevertheless, does not give any examples for this class, although, in our understanding, abbess, e.g., is an office rather than a title, and we would think that poetess means an occupation rather than a rank.

Gottsched [1762, cited after Mitchell 1978: 245-246] makes another attempt to systematize female personal nouns which leads to an inconsistency on the one hand and to ideologization of grammar on the other: He distinguishes between occupational terms for women "when these are really engaged themselves" ("wenn diese wirklich selbst in Diensten stehen"), such as Kammerfrau 'lady-in-waiting' and designations for women "where the womenfolk are not on duty themselves" ("wo das Frauenvolk nicht selbst die Dienste thut"). In this case, they "retain the name of their husbands with a feminine ending" ("behalten sie den Namen ihrer Männer, mit einer weiblichen Endung"), e.g., Ministerinn 'minister-ess', Professorinn 'professor-ess'. The inconsistency lies in the fact that in another place (see above) he cites nouns with the same feminine ending as Bäuerinn 'peasant' and Köchin 'cook' as designations of occupations (i.e., the women are themselves in charge), as well as Äbtissinn 'abbess' who certainly does not "retain the name of [her] husband".

These changes as compared to the presentation of gender in earlier grammars, although few, are significant in that they show clear attempts at a de-parallelization of the male and the female: 1) by introducing systematic differences in the description and making them seem larger and more general than they really are and 2) by presenting the masculine gender as something naturally regular and the feminine as something potentially aberrant. This significance is corroborated by the fact that a contemporary grammar by Aichinger [1754: 191-192] treats the phenomenon of feminization in a more differentiated and empirically adequate manner: "Thus we move ${ }^{6}(\ldots)$ the male offices, ranks, crafts and manners, within which a woman is either what the man is, too, e.g., prince, princess, landlord, landlady, peasant, peasant-f, fool, fool-f, thief, thief-f; or are just named after their husband, as:

${ }^{6}$ i.e., we feminize 
maire-f, vicar-f, judge-f, carpenter-f, shoemaker-f." ("Es werden demnach bewegt (...) Die männlichen Ämter, Würden, Handwerke und Lebensarten, in deren Ansehung ein Weib entweder auch ist, was der Mann ist, z.B. Fürst, Fürstinn, Wirth, Wirthinn, Bauer, Bäuerinn, Narr, Närrin, Dieb, Diebinn; oder nur nach ihrem Ehemanne genennet wird, als: Bürgermeisterinn, Pfarrerinn, Richterinn, Schreinerinn, Schusterinn.”) Aichinger's example shows that Gottsched's view is not the only way of grammatical thinking at that time (there are also other voices as [Meiner 1781, Becker 1836, Brugmann, cp. Naumann 1986: 187-200, Leiss 1994, 2000]), but a deliberate choice.

In his grammar "Umständliches Lehrgebäude der deutschen Sprache" [1782] the distinguished linguist Johann Christoph Adelung extends the philosophical introduction to the category of gender we first found in Gottsched's Sprachkunst to a treatise of five pages length in which he argues that 1) grammatical gender is a basic category of every language and that 2) the reason for the existence of grammatical genders lies in the imagination of the savage, who saw everything as animate or having a soul. As Gottsched, he does not start from a logical origin of gender; on the contrary, it is the nature of uncivilised people who first created language that is responsible for the chaotic distribution of nouns to the three genders. Adelung even hypothesises that because of the pervasiveness of sex in living beings, there were first only two grammatical genders, which were assigned to nouns based on their semantic content, so that nouns corresponding to "the concepts of liveliness, activity, strength, size, probably also the terrifying and awful became masculine; everything one thought of as receptive, fertile, gentle, suffering, agreeable became feminine." ("Alles, was den Begriff der Lebhaftigkeit, Thätigkeit, Stärke, Größe, auch wohl des Furchtbaren und Schrecklichen hatte, ward männlich; alles, was man als empfänglich, fruchtbar, sanft, leidend, angenehm dachte, ward weiblich" [Adelung 1782: 346]). Only later, when people came to understand that most things were inanimate, the neuter gender came into being and was assignd to nouns "when the feelings were divided or the concept so dark that none of the former feelings overweighed the other" [Adelung 1782: 346]. It is interesting to note that Adelung relates grammatical gender to natural gender on the one hand, and, on the other, - to characteristics which we nowadays know as gender stereotypes. As we have seen, this is the first time in German grammaticography where such a relationship is established, and it is completely in line with cultural history [cp. Laqueur 1992: 175, 1990, ch. 5]. The deparallelization of the two sexes is also noticeable in the choice of examples for language phenomena and in a noticeable surplus of masculine examples: in order to illustrate the declension of nominalized adjectives Adelung [1782: 661] gives der Weise 'the wise man' and die Schöne 'the beautiful woman'. In his work 'Über den deutschen Styl" ('on German style', [Adelung 1787]), too, there is a chapter about forms of address, where only male persons are addressed, i.e., we find only masculine examples.

Gender stereotypes can be found in different places in the succeeding grammars: Becker [1824: 56], who does not subscribe to the view that grammatical gender in inanimate nouns is related to natural gender via stereotypes, still draws a parallel between active and passive word-formation suffixes and the masculine and feminine genders, but without becoming too explicit: "The difference between the active and the passive person first appears in the forms teacher, educator and trainee, pupil: in a wider sense it also includes the difference of the masculine and feminine genders." ("Die Differenz der thätigen und leidenden Person erscheint zunächst in den Formen Lehrer, Erzieher und Lehrling, Zögling: in einem weitern 
Sinn umfaßt sie auch die Differenz des männlichen und weiblichen Geschlechts.") So, we see that the discourse relating natural gender to grammatical phenomena via stereotypes is a regular element of discourse in the 19th century.

This kind of discourse is revealed most consequently in Jacob Grimm's grammar of 1831 [Grimm 1890]. The chapter on gender is very large (over 50 pages) and starts with the same comparison Becker used, but in contradistinction to the former, the parallelism is explicated and stated as fundamental: "This difference reaches so far into the essence of the noun and its forms as does the one between the active, passive and medium in the verb. Both classifications may be compared in more than one respect; $[\ldots]$ the active shows itself as the masculine as the most important and initial form, the passive as the feminine as one which is derived from the former, the medium as the neuter as a mixture or combination of active and passive, male and female forms" ("Dieser unterschied greift so tief in das wesen des nomens und seiner formen wie der zwischen activum, passivum und medium in die des verbums. Beide eintheilungen laßen sich in mehr als einer hinsicht vergleichen; [...] das activum erscheint wie das masculinum als die wichtigste und ursprünglichste form, das passivum wie das femininum als eine aus jenem abgeleitete, das medium wie das neutrum als eine mischung oder verbindung activer und passiver, männlicher und weiblicher formen." [Grimm 1890: 307]). In the same passage Grimm also states that the three genders are in a way three languages, since a man says pulcher sum ('I am beautiful.m'), a woman pulchra sum ('I am beautiful.f') and a child pulchrum sum ('I am beautiful.n'). In such a way, we immediately relate the comparison between two grammatical cateogries - voice and gender - via metaphor to gender stereotypes and thus to natural gender. This system of metaphors as well as the comparison of the masculine with the active, the feminine with the passive, and the neuter with the medium is pervasive in Grimm's grammar and emerges everywhere where the topic of gender is treated. Grimm introduces a lot of stereotypes which are very often also evaluative and demonstrate the higher rank of the masculinemale over the feminine-female. E.g., he thinks of the masculine as "the most vivacious, strong and initial form", which, he argues, is corroborated by the fact that the masculine form usually ends in a strong, consonantal ending, which he terms "strict", whereas the feminine usually ends in a "soft" -a. If the masculine form ends in a vowel, it is a short one, whereas feminine forms have long vowels, and this again shows the distinction of the masculine, since short vowels are obviously "older and more noble" than the long ones which are dependent on the former [Grimm 1890: 309]. Grimm's discourse is typical of Romanticism and is not repeated in the following, modernistic and thus more rational, grammars (with the exception of the Duden grammars [1935, 1966], but in a very abridged form). Yet, his way of thinking has influenced generations of linguists in their thinking about the origin of gender until the end of the $20^{\text {th }}$ century [Leiss 1994].

The period after Grimm is less emotional in grammaticography, but very emotional if manuals of style are taken into consideration, which become more and more important at the fin de siècle and afterwards (e.g. [Bennewitz 1920, Engel 1918, Wustmann]). Here, the use of the right gender for the designation of women but also for ships and other objects is discussed. Manuals of style argue for the use of feminine nouns for women and the reservation of masculine nouns for men (cp. [Doleschal 2002]). This is interesting, since in the 1970s women had to fight for the recuperation of the right to feminine nouns. In the time after 1945, the view on the relationship between grammatical and natural gender 
changed radically and grammars now state that grammatical gender is a purely formal feature of nouns that has nothing to do with natural gender of human or other living beings, arguing that there are 1) nouns with feminine gender denoting men (e.g., die Waise 'orphan') and 2) that masculine nouns are gender-neutral and denote persons as such, e.g.: "it does not actually denote a male person, but rather (without regard of natural gender) just the subject of behaviour." ("Lehrer ist, wer zum Beruf das Lehren gewählt hat; Lehrerin ist dazu die moderne weibliche Variante. Im Verhältnis der beiden Varianten ist das Masculinum das Grundwort. Es nennt eigentlich nicht eine männliche Person, sondern (ohne Rücksicht auf das natürliche Geschlecht) allein das Subjekt eines Verhaltens." [Brinkmann 1962: 19-20]) It is also interesting to find that in the second half of the $20^{\text {th }}$ century, the derivation of feminine nouns by the suffix -in which was presented as a fully productive process by all grammars up to the end of the $19^{\text {th }}$ century and especially by the manuals of style is now seen as something difficult or "new" (cp. the quotation above).

Only from the 1980s on, the discourse on gender in German grammars ([Eisenberg 1986, Hentschel, Weydt 1990]) has again been free from ideological positions, while also describing the facts in a more adequate way than did the grammarians of the $16^{\text {th }}$ and $17^{\text {th }}$ centuries.

\section{Conclusions}

Linguistic thought and linguistic description are bound to their time and reflect contemporary ideologies by setting up language ideologies. Although this relationship is not a deterministic one, i.e., other positions are also possible, the mainstream usually reflects the mainstream currents of thought. It is especially interesting to note that the change in discourse may be abrupt as we have noticed both for the 18th and the second half of the 20th century, and there is no need to refer to earlier views. What we have also seen is that the degree of ideologisation of grammatical discourse can vary greatly: Whereas during Renaissance and Baroque as well as during the Postmodern time we find rather neutral discussions of gender, the period of Enlightenment, Romanticism and Modernism are periods where the topic "gender" was highly ideologised.

\section{References}

Doleschal, Ursula (2002). Das generische Maskulinum im Deutschen. Ein historischer Spaziergang durch die deutsche Grammatikschreibung von der Renaissance bis zur Postmoderne. Linguistik online 11/2. Available from: http://www.linguistik-online. de/11_02/, 39-70.

Jellinek, Max Hermann (1913-1914). Geschichte der neuhochdeutschen Grammatik von den Anfängen bis auf Adelung (Vol 1-2). Heidelberg, Winter.

Laqueur, Thomas (1990). Making Sex. Body and gender from the Greeks to Freud. Cambridge, Mass., Harvard Univ. Press.

Laqueur, Thomas (1992). Auf den Leib geschrieben. Frankfurt/New York: Campus. (German translation of 1990).

Leiss, Elisabeth (1994). Genus und Sexus. Kritische Anmerkungen zur Sexualisierung von Grammatik. Linguistische Berichte 152, 281-300. 
Leiss, Elisabeth (2000). Gender in Old High German. In: Unterbeck, Barbara/ Rissanen, Matti (eds.) Gender in Grammar and Cognition. Berlin/New York, Mouton de Gruyter, 237-258.

Naumann, Bernd (1986). Grammatik der deutschen Sprache zwischen 1781 und 1856. Die Kategorien der deutschen Grammatik in der Tradition von Johann Werner Meiner und Johann Christoph Adelung. Berlin, Schmidt.

Roessler, Paul (1997). Die deutschen Grammatiken der zweiten Hälfte des 18. Jahrhunderts in Österreich. Frankfurt a. M., Lang.

Žepić, Stanko (1998). Deutsche Grammatiken kroatischer Verfasser in der zweiten Hälfte des 18. Jahrhunderts. Frankfurt a. M., Lang.

\section{Sources}

Adelung, Johann Christoph (1782): Umständliches Lehrgebäude der Deutschen Sprache zur Erläuterung der Deutschen Sprachlehre für Schulen. 1. Bd. Leipzig, Breitkopf.

Adelung, Johann Christoph (1787): Über den deutschen Styl. Berlin, Voß.

Aichinger, Carl Friedrich (1754): Versuch einer teutschen Sprachlehre. Wien, Kraus. (reprint 1972 Hildesheim, Olms).

Albertus, Laurentius (1573) Teutsch Grammatick oder Sprachkunst. Augsburg, Michael Manger. (Müller-Fraureuth 1895)

Basler, Otto (1935) Der große Duden. Grammatik der deutschen Sprache; eine Anleitung zum Verständnis des Aufbaus unserer Muttersprache. Leipzig, Bibliographisches Institut.

Becker, Karl Ferdinand (1824) Die deutsche Wortbildung oder die organische Entwicklung der Sprache in der Ableitung. Frankfurt a.M., Hermann.

Becker, Karl Ferdinand (1836) Ausführliche deutsche Grammatik als Kommentar der Schulgrammatik. Frankfurt a.M., Hermann.

Behaghel, Otto (1930 [1886]) Die deutsche Sprache. Leipzig, Freytag.

Bennewitz, A. (1920) Die Schwierigkeiten unserer Muttersprache. Leipzig, Gloeckner.

Blatz, Friedrich (1900) Neuhochdeutsche Grammatik mit Berücksichtigung der historischen Entwickelung der Deutschen Sprache. 3. völlig neu bearbeitete Auflage in 2 Bänden. Karlsruhe, Lang.

Bödiker, Johannes (1698) Grund-Sätze der Teutschen Sprache. Berlin, Meyers Erben u. Zimmermann.

Braun, Heinrich (1765) Anleitung zur deutschen Sprachkunst, zum Gebrauche der Schulen in den Churlanden zu Baiern. München, Ott.

Brinkmann, Hennig (1962, 1971) Die deutsche Sprache. Gestalt und Leistung. Bd. 1. Düsseldorf, Schwann.

Clajus, Johannes (1578) Grammatica germanicae linguae ex optimis quibusque autoribus collecta. Leipzig. (Weidling 1894)

Drosdowksi, Günther et al. (1984) Duden-Grammatik. Mannheim, Duden Verlag.

Drosdowksi, Günther et al. (1995) Duden-Grammatik. Mannheim, Duden-Verlag.

Duden Grammatik (1935) (Basler 1935)

Duden Grammatik (1966) (Grebe et al. 1966) 
Duden Grammatik (1973) (Grebe et al. 1973)

Duden Grammatik (1984) (Drosdowksi et al. 1984).

Duden Grammatik (1995) (Drosdowksi et al. 1995).

Duden Grammatik (1998) (Eisenberg et al. 1998).

Eichler, Wolfgang/Bünting, Karl-Dieter (1976), Deutsche Grammatik. Form, Leistung und Gebrauch der Gegenwartssprache. Kronberg/Ts., Athenäum.

Eisenberg, Peter (1986) Grundriß einer deutschen Grammatik. Stuttgart, Metzler.

Eisenberg, Peter (1998) Grundriß der deutschen Grammatik. Bd. 1. Das Wort. Stuttgart, Metzler.

Eisenberg, Peter (1999) Grundriß der deutschen Grammatik. Bd. 2. Der Satz. Stuttgart, Metzler.

Eisenberg, Peter et al. (1998) Duden-Grammatik. Mannheim, Duden-Verlag.

Engel, Eduard (1918) Gutes Deutsch. Ein Führer durch Falsch und Richtig. Leipzig, Hesse und Becker.

Engel, Ulrich (1988) Deutsche Grammatik. Heidelberg, Groos.

Engelien, August (1902 [1867]) Grammatik der neuhochdeutschen Sprache. Berlin. [Reprint 1972, Hildesheim, Olms]

Erben, Johannes (1965 [1958]) Abriß der deutschen Sprache. Berlin, AkademieVerlag.

Erben, Johannes (1972) Deutsche Grammatik. Ein Abriß. München, Hueber.

Fleischer, Wolfgang et al. (Hg.) (1983) Kleine Enzyklopädie. Deutsche Sprache. Leipzig, Bibliographisches Institut.

Gottsched, Johann Christoph (1749) Grundlegung einer deutschen Sprachkunst. Leipzig, Breitkopf.

Gottsched, Johann Christoph (1762) Vollständigere und Neuerläuterte Deutsche Sprachkunst. Leipzig: Breitkopf. (Mitchell 1978)

Grebe, Paul et al. (1966) Duden-Grammatik. Mannheim, Duden-Verlag.

Grebe, Paul et al. (1973) Duden-Grammatik. Mannheim, Duden-Verlag.

Grimm, Jacob (1890 [1831]) Deutsche Grammatik. Dritter Theil. Neuer vermehrter Abdruck besorgt durch Gustav Roethe und Edward Schroeder. Berlin, Dümmler.

Grimm, Jacob (1898 [1837]) Deutsche Grammatik. Vierter Theil. Neuer vermehrter Abdruck besorgt durch Gustav Roethe und Edward Schroeder. Berlin, Dümmler.

Gueintz, Christian (1641) Deutsche Sprachlehre. Entwurf. Cöthen [reprint 1978, Hildesheim, Olms]

Heidolph, Karl-Erich et al. (1981) Grundzüge einer deutschen Grammatik. Berlin, Akademie-Verlag.

Hentschel, Elke/Weydt, Harald (1990) Handbuch der deutschen Grammatik. Berlin, de Gruyter.

Heynatz, Johann Friedrich (1774) Briefe die deutsche Sprache betreffend. Berlin, Mylius.

Heynatz, Johann Friedrich (1770) Deutsche Sprachlehre zum Gebrauch der Schulen. Berlin, Mylius.

Jung, Walter (1966) Grammatik der deutschen Sprache. Leipzig, Bibliographisches Institut. 
Meiner, Johann Werner (1781) Versuche einer an der menschlichen Sprache abgebildeten Vernunftlehre oder Philosophische und allgemeine Sprachlehre. Leipzig, Breitkopf.

Mitchell, P.M. (1978) Johann Christoph Gottsched. Ausgewählte Werke. Achter Band. Deutsche Sprachkunst bearbeitet von Herbert Penzl. Berlin, de Gruyter.

Müller-Fraureuth, Carl (1895) Die deutsche Grammatik des Laurentius Albertus. Straßburg, Trübner.

Oelinger, Albertus (1574) Underricht der Hoch Teutschen Spraach, Grammatica. Straßburg (reprint1975, Hildesheim, Olms).

Paul, Hermann (1916-1920) Deutsche Grammatik. 5 Bde. Halle a.S., Niemeyer.

Ritter, Stephan (1616) Grammatica germanica nova. Marburg.

Schottel, Justus Georg (1663) Ausführliche Arbeit von der teutschen Haubtsprache. Braunschweig, Zilliger.

Stieler, Kaspar von (1691) Der teutschen Sprache Stammbaum und Fortwachs oder teutscher Sprachschatz. Nürnberg, Hofmann.

Sütterlin, Ludwig (1900) Die deutsche Sprache der Gegenwart. Leipzig, Voigtländer.

Sütterlin, Ludwig (1924) Neuhochdeutsche Grammatik mit besonderer Berücksichtigung der neuhochdeutschen Mundarten. 1. Hälfte. München, Beck.

Weidling, Friedrich (Hg.) (1894) Die deutsche Grammatik des Johannes Clajus nach dem ältesten Druck von 1578 mit den Varianten der übrigen Ausgaben. Straßburg, Trübner.

Weinrich, Harald (1993) Textgrammatik der deutschen Sprache. Mannheim, DudenVerlag.

Wilmanns, Wilhelm. (1899) Deutsche Grammatik. Gotisch, Alt-, Mittel- und Neuhochdeutsch. II. Abteilung, Wortbildung. Straßburg, Trübner.

Wilmanns, Wilhelm. (1909) Deutsche Grammatik. Gotisch, Alt-, Mittel- und Neuhochdeutsch. III. Abteilung, Flexion. 2. Hälfte: Nomen und Pronomen. Straßburg, Trübner.

Wustmann, Gustav (1908) Allerhand Sprachdummheiten. Leipzig, Grunow.

Wustmann, Gustav (1917) Allerhand Sprachdummheiten. Straßburg, Trübner.

Wustmann, Gustav (1943) Allerhand Sprachdummheiten von Werner Schulze. Berlin, de Gruyter.

Wustmann, Gustav (1966) Allerhand Sprachdummheiten von Werner Schulze. Berlin, de Gruyter.

Zifonun, Gisela et al. (1997) Grammatik der deutschen Sprache. Bd. 1. Berlin, IDS.

(C) Doleschal U., 2021 
Article history:

Received: 19.07 .2021

Accepted: 20.09.2021

\section{Bionotes:}

Ursula Doleschal - Univ.-Prof. Mag. Dr. in Alpen-Adria-Universität Klagenfurt, Institut für Slawistik.

\section{Contact information:}

Alpen-Adria-Universität Klagenfurt, Universitätsstraße, 65-67, 9020 Klagenfurt am Wörthersee, Austria

ORCID: https://orcid.org/0000-0002-1164-5635

e-mail: ursula.doleschal@aau.at

\section{For citation:}

Doleschal, U. (2021) Gender, grammar and discourse: the case of German. Journal of Psycholinguistics. 3(49), pp. 74-85. Available from: doi: 10.30982/2077-5911-2021-49-374-85 